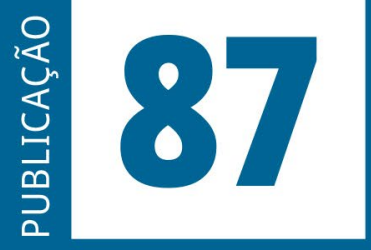

ISSN: 0101-9562

ISSN ELETRÔNICO: 2177-7055

SEQÜENCIA

Publicação do

Programa de Pós-Graduação em Direito da UFSC

VOLUME 42 - ANO 2021
Estudos jurídicos e políticos 
SEQUÊNCIA - ESTUDOS JURÍDICOS E POLÍTICOS é uma publicação temática e de periodicidade quadrimestral, editada pelo Programa de Pós-Graduação Stricto Sensu em Direito da Universidade Federal de Santa Catarina - UFSC.

SEQUÊNCIA - ESTUDOS JURÍDICOS E POLÍTICOS is a thematic publication, printed every four months, edited by the Program in law of the Federal University of Santa Catarina - UFSC.

Versão eletrônica: http://www.periodicos.ufsc.br/index.php/sequencia

A publicação é indexada nas seguintes bases de dados e diretórios/

The Publication is indexed in the following databases and directories:

Base OJS

Base PKP

CCN (Catálogo Coletivo Nacional)

Dialnet

DOAJ (Directory of Open Access Journals)

EBSCOhost

Genamics Journalseek

ICAP (Indexação Compartilhada de Artigos de Periódicos)

Latindex

LivRe!

OJS
PKP
Portal de Periódicos UFSC
Portal do SEER
ProQuest
SciELO
Sherpa/Romeo
Sumarios.org
ULRICH'S
vLex

Ficha catalográfica

Seqüência: Estudos jurídicos e políticos. Universidade Federal de Santa Catarina.

Programa de Pós-Graduação em Direito. n.1 (janeiro 1980)-.

Florianópolis: Fundação José Boiteux. 1980-.

Publicação contínua

Resumo em português e inglês

Versão impressa ISSN 0101-9562

Versão on-line ISSN 2177-7055

1. Ciência jurídica. 2. Teoria política. 3. Filosoia do direito. 4. Periódicos.

I. Universidade Federal de Santa Catarina. Programa de Pós-graduação em

Direito

CDU 34(05)

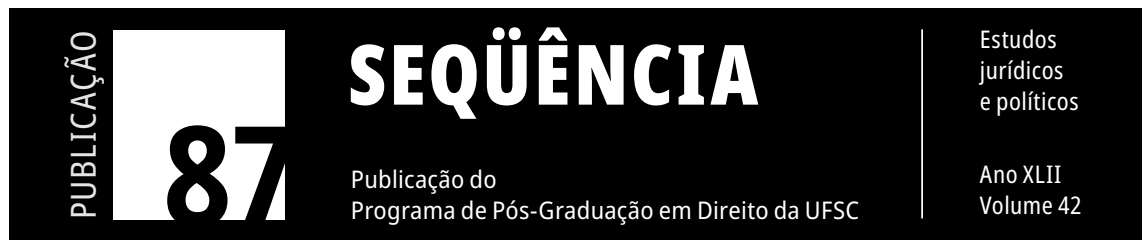




\title{
A genealogy of the critical discourses on the authoritarianism of the Brazilian Criminal Procedure Code
}

\author{
Uma genealogia dos discursos críticos sobre o autoritarismo \\ do Código de Processo Penal brasileiro
}

Clara Maria Roman Borges

Universidade Federal do Paraná, Curitiba, Brazil

ABSTRACT: This paper presents an investigation on the critical discourses that attribute the authoritarianism of the Brazilian criminal procedure to a legacy of the fascist Italian criminal procedural legislation of 1930. At first, it reveals the impossibility of this comparison by the lack of sources for verifying if there was indeed the influence of Italian fascist law in the Brazilian Criminal Procedure Code of 1941. Then, it is analyzed how this critical discourse diffuses among Brazilian criminal procedural law scholars from the 1990's, due to their networks of academic and professional contacts, establishing a rupture with previous criticisms. Finally, the research aims to demonstrate how this approach between the Brazilian Code and the Rocco Code was artificial and prevents Brazilian criminal procedural law scholars from realizing the influences of other foreign laws in legislation and current judicial practices and prevents them from creating strategies to ensure the implementation of constitutional guarantees in these new procedural forms.

KeYWORDS: Genealogy - Critical discourses - Brazilian Criminal Procedure Code.

RESUMO: Este artigo apresenta uma pesquisa sobre os discursos críticos que atribuem o autoritarismo do processo penal brasileiro a um legado da legislação processual penal italiana fascista de 1930. Em primeiro lugar, revela a impossibilidade desta comparação, em razão da falta de fontes que possibilitem verificar se realmente houve influência da legislação fascista no Código de Processo Penal Brasileiro de 1941. Então, analisa-se como esses discursos críticos difundidos entre os estudiosos 
do processo penal brasileiro nos anos de 1990 e estabeleceram uma ruptura com o discurso crítico anterior. Finalmente, a pesquisa objetiva demonstrar como a aproximação entre o Código de Processo Penal Brasileiro e o Código Rocco foi artificial e pode ter contribuído para que os processualistas penais não percebessem as influências de outras legislações estrangeiras no processo penal e nas práticas judiciais brasileiras, e, consequentemente, pode ter impedido que criassem estratégias para implementar as garantias constitucionais nessas novas formas processuais.

Palavras-Chave: Genealogia - Discursos críticos - Código de Processo Penal Brasileiro.

\section{INTRODUCTION}

By analyzing the critical discourses to the authoritarianism of the Brazilian criminal procedure, it is possible to realize that most of them apply the same arguments to explain the constant violation of constitutional guarantees and its use for the criminalization of politics. Usually, without any bibliographical references or the text of the law, these discourses affirm that the Brazilian criminal procedure is authoritarian because the current Code of Criminal Procedure (BRAzIL, 1941), promulgated in 1941, would be inspired by the Italian Code of Criminal Procedure 1930, or because it is a poor copy of fascist legislation (ITALY, 1930).

Despite these strong criticisms made mainly by lawyers, but also by judges, prosecutors and academics, Brazilian society has recently followed two important criminal cases, which had media repercussions and served for the political persecution of certain groups, one related with the "Mensalão" scandal and the other to "Operation Car-wash", in both of which various rights of the defendants were violated on the grounds that the end would justify the means, in other words, that the constitutional guarantees would not be so important, when the goal is to place under arrest corrupt politicians.

Thus far, these critical discourses were not effective in containing the reported authoritarianism and failed to prevent the consolidation 
of criminal bargaining away from constitutional guarantees such as presumption of innocence, parity of arms and due process of law, and to prevent the use of other foreign procedural institutes without observing the rights assured to the defendants and the limits of the Brazilian State sovereignty.

So, it is inevitable to question the possible purposes that have made this critical discourse unable to suggest and promote changes in the Brazilian criminal procedure that could make it resistant to the unconstitutional bargains, invasive procedures to produce evidence, and other institutes not provided in the Criminal Procedure Code.

In order to answer these questions, it is necessary to follow the recent history of Brazilian criminal procedural law, but not without due methodological precautions. To understand the context of the production of these failed critical discourses, it is necessary to investigate their subjects, the power relations that permeates them and the true effects produced by them. In other words, how these discourses spread through and were repeated in academic circles and in legal practices. Therefore, Foucault's genealogy was chosen as a methodological tool to develop the research proposal and try to answer the questions formulated, avoiding in this way the search for origins, staying away from a monumental and metaphysical history, worrying about the discontinuities, the ruptures of the critical discourses on the authoritarianism of the Brazilian criminal procedural. Comprehending thus the subjection perpetrated by the protagonists and diffusers of these discourses and the subjectification suffered by them.

It is pointed out that this article aims to present partial results of the proposed research, because there is much to explore about the theme subject and some reflections need time to mature and generate other questions that will allow refined approximation to what intends to understand and prove, more specifically, how a misleading historical approach was used by Brazilian critical discourses on authoritarianism of the criminal procedure, preventing law scholars from observe foreign influences in contemporary legislation and avoiding violations 
of procedural guarantees arising from the new institutes, as well as political use of the criminal process.

\section{METHODOLOGICAL PRECAUTIONS}

The difficulties of doing a historiography of the recent Brazilian criminal procedure appear early in the research. The current Brazilian Code of Criminal Procedure, promulgated in 1941, was produced by a technical Commission appointed by President Getúlio Vargas.

It seems that by the historical indications already examined by other authors that the work of Commission was to adapt the previous legislation and law projects to the needs of the nascent dictatorial state. However, there is no way to analyze deeply the activities of the Commission composed by Vieira Braga, Nelson Hungria, Narcélio de Queiroz, Roberto Lyra, Florêncio de Abreu and Professor Cândido Mendes de Almeida, because there is no record of this in archives or newspapers. It is possible to trace only a few comments from the members of the Commission on the legislation they produced, as well as some explanations given by the Minister of Justice, Francisco Campos, responsible for orchestrating the legislative reforms of that moment.

It means that any discourse that aims to treat the history of Brazilian Criminal Procedure Code should not be categorical in statements about the purposes of the Commission neither to the influence of foreign legislation at the time of its preparation.

In this sense, the lack of primary sources about the discussions that produced this legislation is a warning to the researchers not to rush with suppositions about the choice or not of certain procedural model in Brazil of the 1940s. They can formulate questions about the indications left in the legislation produced, about the comments made by jurists of that time, about the culture that circulates in academy at that time and among the members of the Commission, 
about the intellectual development and production of the members of the Committee. Only after a meticulous investigation to answer these questions a researcher can conjecture about the Commission's intentions and possible influences of other legislations in the Criminal Procedure Code. This is because the comparison between this legislation and others of that time allows concluding that it is not at all a simple copy of another legal text.

For these reasons, causes strangeness the criticism disseminated by Brazilian law scholars since the 1990s states that the 1941 Code is a poor copy or is inspired by the 1930 fascist Italian legislation of which would have inherited inquisitorial and authoritarian forms, without any literal reference to the laws or bibliographical. Thus, it is a critical discourse that appropriates the history of Brazilian criminal procedure to legitimize a political purpose of denouncing violations of rights and constitutional guarantees of the defendants, which is repeated incessantly to the point that led up to a blindness to the influence of other legislations that were transforming the Brazilian criminal procedure over the last 78 years.

Therefore, in order to comprehend how this criticism was formed and was disseminated at least in the last 20 years, and especially to ask the necessary questions to understand its effects on contemporary judicial practices, the Foucauldian genealogy is chosen.

This choice primarily was because this research intends to analyze the academic discourses whereas the subjects who produced them, the inadequate appropriation that they made of procedural history to gain acceptance, also the true consequences that these discourses produced by its diffusions, and the power relations that permeated these processes.

The Foucauldian genealogy, founded on the thought of Friedrich Nietzsche, aims to denounce the use of a metaphysical history, which searches for the origin of events as if at the beginning of things was its essence or something is given, a place of truth. The genealogical tool offered by Michel Foucault points to a historical sense that denies the 
linearity of history, worrying about ruptures, destroys monumental history, which is dedicated to maintaining the presence of great works, of great actions and creations, covering the intensity of the present life. The genealogy refuses the search for a continuity in which our present is rooted, contributing to the preservation of that past that is present (Foucault, 1977).

Furthermore, this tool will reveal the metaphysical history engendered in this critical discourse on the authoritarianism of the criminal procedure, which possibly conducted the law research for years, also will allow investigating the moment of rupture in the critique of Brazilian criminal procedure law and the factors that may have contributed to this change. Finally, the genealogy will help to understand how the Brazilian legislation, which conditions the judicial practices and by them is conditioned, is not the same writing and applied in 1941, and that legislation does not immediately refer to a frozen moment in the past that is preserved in the present without being subject to relations of power, their strategies of dominations.

In synthesis, the genealogy seeks to generate new possibilities for understanding the characteristics of the Criminal Procedure Code of 1941, the critical discourses of this legislation and the current practices of the Brazilian criminal process, although analytical distance of time is not achieved to historicize more coldly because of the temporal proximity of the facts (SEelaender, 2017).

\section{SOME CLUES ABOUT THE BRAZILIAN CRIMINAL PROCEDURE CODE OF 1941}

As mentioned, the Brazilian archives did not keep the records of the Committee meetings that were responsible for the elaboration of the Criminal Procedure Code of 1941. We have some clues about the work of the jurists in the explanatory statement of this legislation, authored by the Minister of Justice Francisco Campos, also some 
manifestations of the Commission members and books with comments about the new law published thereafter the enactment of the Code.

As it is a matter of public knowledge, the years before the promulgation of the Brazilian Criminal Procedure Code of 1941 were marked by intense political disputes. Initially, the conflict was established between groups that formed the Liberal Alliance, a supporter of Getúlio Vargas in the elections that culminated in the establishment of his provisional government in 1930. One side of the conflict were the military that yearned for a centralizing, interventionist, nationalist and reformist State, and on the other side were the dissident oligarchs who defended liberal and federative proposals that limited the power of federal Union and gave autonomy to the States.

On this first period of Vargas government, the answer given to these demands anticipated the project that the President had in mind, because it was centralizer and interventionist, but did not have unanimous acceptance of the allies, only exacerbating the existing disputes, which culminated in the Constitutionalist Revolution of 1932. The failure of Vargas to keep the promise to call new elections and a constitutional assembly as soon as he took office caused dissatisfaction of civilians and military, which was the catalyst to this armed uprising carried out by the paulistas against presidential troops composed forces from various regions.

In spite of the military defeat of the insurgents of São Paulo, it is necessary to recognize that they had important political gains, mainly the promulgation of a new Constitution in 1934, which expressed the liberal democratic ideology that limited the executive power, explicitly established women's right to vote and opened space for direct elections in 1938. These changes stimulated political participation and strengthened social movements, granting several strikes occurred across the country and new party or nonpartisan organizations emerged, such as the Brazilian Integralist Action (AIB) and the National Liberating Action (ANL) that mobilized the country. As a reaction, the National Liberating Action was placed an underground movement, and several 
changes began to be made in the newly approved Constitution, which increased the Executive's repressive power, beginning a gradual closure of the regime. (Pandolfi, 2003)

In April 1935, Congress passed the National Security Law (Lei n. 38) which abolished several democratic constitutional guarantees for who participated in demonstrations aimed subverting political and social institutions. Then the National Liberating Action, with the support of the communist party, obtained the adhesion of soldiers and under the leadership of Luis Carlos Prestes commanded uprisings across the country with the objective of overthrow Getúlio Vargas and install a popular government. Although this rebellion called the Communist Intentone was quickly and violently overthrow, under a state of war decree's, this event served as a pretext for Getúlio Vargas to try to prolong his term under the argument it was necessary to restore order, but the intention wouldn't get support from the Parliament.

Violent clashes between communists and integralists threatened democratic institutions. The presidential election approached and was released three candidates by groups dissatisfied with the Vargas government. The moment was one of instability and there was fear of revolutionary articulations, and this fear was even explored by those who wanted the increase the repression, as happened in the case of the military that forged a supposed threat of uprising by a Jewish-communist movement, in the episode that became known as the Cohen Plan.

The result of this repressive escalation occurred on November 10, 1937, when President Getúlio Vargas determined that troops surround the Parliament building and impose the new Constitution, written by the jurist Francisco Campos, which started the New State in Brazil (PAndolfi, 2003).

This was a state model that devalued democratic institutions, such as Parliament and political parties, seen as the focus of social disruption and obstacles to government contact directly with the people, to setting the new nation project in motion. Thus, the new regime 
established itself as nationalist, anti-partisan and anti-communist (Sontag, 2009, p. 37).

In short, in an open dictatorship, Getúlio Vargas ruled the country during 1937 to 1945 without being submitted to the control of the legislative power, the judiciary, political parties and state leaders, thus he centralized all political decisions and acted through decree-laws (PAIXÃO, 2011).

In this scenario, the broad process of legislative reforms that initiated in $1931^{\mathrm{I}}$, with the establishment of the provisional government of Vargas, totally changed direction. If at the first moment Vargas created several subcommittees for jurists and State discuss the revision of current laws, and the majority of these discussions were published in important newspapers of the Brazilian Republic, in the period of New State new legislative committees were appointed by the Minister of Justice and the publication of their discussions became less frequently.

A Review Commission was called to present a project of Criminal Procedure Code based on the projects discussed by the previous committees. This Commission was initially composed by Nelson Hungria, Narcélio de Queiroz, Cândido Mendes and Antonio Vieira Braga. In the second stage of the work, Roberto Lyra and Florêncio de Abreu e Silva were invited to join the Committee. It's important to note that none of them had specific intellectual production about criminal procedural law, except Cândido Mendes, who died before the end of the work (VAlle, 2018).

The project was presented by the Commission, with the due adaptations to the project of the new Criminal Code, and then it was

\footnotetext{
By Decree no. 19.459 of December 6, 1930, Getúlio Vargas created the Legislative Committee of the Provisional Government, composed of 19 subcommittees, which one with three jurists of notorious knowledge and reputation, who would receive the suggestions of other jurists, would prepare a project and a report with the main legislative innovations proposed, which would be approved by the Constituent Congress. After approval, the project would be published with an opinion from Congress.
} 
approved and promulgated by Getúlio Vargas through Decree-Law n. 3.689 of December 3, 1941. As mentioned, there is no record of the discussions, so under those circumstances it's impossible to know who acted as rapporteur or reviewer of the project presented by the Commission.

As mentioned previously Cândido Mendes was the only one who had intellectual production on the subjects of the Criminal Procedure Law, and he was responsible for the writing and comments on the Code of Criminal Procedure of the Federal District of 1924, which served as the basis for the Commission's discussions. Besides that, in 1942, Narcélio de Queiroz gave an important lecture about the new Code at the Brazilian Society of Criminology which was also composed of Roberto Lyra and Nelson Hungria. In addition, Florêncio de Abreu has taken a prominent position in several legal events on the new legislation and likewise he was brother-in-law of Getúlio Vargas, that can suggest that he has done relevant work in the Committee (Valle, 2018, p. 80).

These technical committees for drafting the codes were normally composed by Minister of Justice rather than representative Assemblies with the aim of making the new legislation a technical artifact and away from political use (Sontag, 2009). The members of the Commission that produced the Code of Criminal Procedure participated in important academic institutions, such as the Brazilian Society of Criminology and the National Law School of Rio de Janeiro, however their work and discussions of the project weren't shared with these or other representative institutions in the legal world.

The development of the Criminal Procedure Code of 1941 seems to have occurred away from the public space, and the main newspaper for legal matters at that time nothing reported on the Commission activities. Since the promulgation of 1937 Constitution, the only publication in the Revista da Faculdade de Direito da USP on the Criminal Procedure Code was the project elaborated by Vicente Ráo, Antonio Bento de Faria and Plínio de Castro Casado (1938), 
which was not approved. In the same period nothing was published in the Revista Forense, also an important juridical periodical of that time ${ }^{2}$. On September 18, 1941, the Jornal do Commercio, also relevant in the legal Brazilian world, only published the speech of the lawyer Hymalaia Vergulino, at the meeting of the IAB (Lawyers Institute of Brazil), charging the Ministry of Justice on the lack of new procedural legislation, since the Criminal Code had already been promulgated and would come into force in soon ${ }^{3}$. Shortly thereafter, on October 4, the same newspaper announced that the new Criminal Procedural Code would be promulgated and asked the government to publish the legislation projects so that jurists, associations and scientific congregations could make their suggestions to the future Code ${ }^{4}$. The problem

2 On relevant journals in the Vargas government years, see: SILVEIRA, 2011.

3 "Dr. Hymalaia Vergolino suggested that the Institute should already be interested in the judicial organization with regard to the Code of Criminal Procedure, which should be completed as the new Criminal Code enters into force on 1 January 1942. All of us, said the speaker, saw the disturbance on the occasion of the entry into force of the Code of Civil Procedure and so that the facts don't reproduce, we remind the Institute to promote such measures as may be appropriate in this sense, because news of the elaboration of the Code of Criminal Procedure, he the speaker, don't have. The President stated that he would take the request into account, but he could say that the Code of Criminal Procedure is already about to be concluded, and the illustrious Minister of Justice, Dr. Francisco Campos, is engaged with great interest in this task, and this anomaly referred by the speaker will not repeat." (Lawyers Institute, Jornal do Commercio, September 18, 1941).

4 "It's report that the new Code of Criminal Procedure, elaborated by a committee of jurists, guided by the Minister of Justice, is being promulgated in the next days. On the occasion of the publication of the Code of Civil Procedure, of the new decree on 'Stock Companies' and others, were published in the Official Daily the respective ante-projects, to receive suggestions from interested persons. In either case, amendments were offered, accepted and incorporated into the legal text, some of which were a notorious advantage to all those to whom the new law would reach, whether it was the parties, the lawyers, or, finally, the judges and courts. With the new Criminal Procedure Code, it seems that the new system so successful hasn't been adopted; it was, however, imperative to publish the ante-project; so that in the short term - in order not to delay the execution of the Penal Code - the academics, the congregations and scientific associations, on the future unitary code of process, matter of as high relevance as the one to make the march of restriction individual freedoms." (Judicial Branch. Jornal do Commercio, October 04, 1941). 
was that the news delayed, because the Decree-Law n. 3.689, which bring into force the Code of Criminal Procedure, had been signed a day earlier, which leads to the conclusion that society and scientific institutions were surprised by the promulgation of the new legislation. Thus, on October 5, the Jornal do Commercio published a summary of the new Code5. Finally, on October 7, this journal published a note apologizing to the readers for having invited them to submit suggestions to the project of the Code after it had been promulgated and expressing the hope that the new law was perfect and didn't need amendments and rectifications. ${ }^{6}$

One the contrary of the Civil Procedure Code and the Criminal Code drafts, passed respectively in 1939 and 1940, much discussed and commented by the experts, in lectures and articles published in scientific journals and periodicals, the Criminal Procedure Code seems to have been relegated to a second place and its promulgation without warning prevented from the criticism.

Therefore, because of the lack of publicity for the Commission's work and the few manifestations of its members about the discussions, it is not possible to make categorical statements about the ideas that prevailed, the protagonists of the debates, the discourses that had inspired and the influence of other legislations on the Code. However, we have some clues that allow concluding that the project was based on previous legislations (the State Codes) and in the draft of Federal

Code of Criminal Procedure. Signed by the President of the Republic the Decree-Law promulgating it - Summary of its devices. Jornal do Commercio, October 05, 1941.

6 "There was a delay here made on the appropriateness of the publication for suggestions of the draft Code of Criminal Procedure, similarly to what was done in relation to other important laws, among them the Code of Civil Procedure; there was already that Code sanctioned by the eminent Head of Government when we deal with the matter. There remains, however, the certainty that we have echoed the opinion of all those in and out of it who are interested in the new and important legal instrument, and we express the wish that its practical application proves to be an effective, perfect work without deficiencies or excesses, to demand in the short term, amendments and corrections." (Judicial Party. Jornal do Commercio, October 7, 1941). 
District Code (1924) ${ }^{7}$ and Vicente Rao Project (1936) (RÁo; Faria; Casado, 1938).

This is because the explanatory statement of the Criminal Procedure Code, written by the Minister of Justice, Francisco Campos, explains that

The project doesn't change the current law, but corrected its defects identified by the experience, resolve uncertainties of jurisprudence or prevent the versatilities of exegetes. As much as was allowed by the orientation of the project, the material of the current legislation was used. Much was compiled of the state's criminal procedure codes, also was take into account the project made by the Legislative Committee nominated by the Provisional Government in 1931, as well as the 1936 Project, which was already guided by the objective of unification of criminal procedural law (CAMPOS, 1941, p. 628) .

It is true that in the new Code some innovations can be identified in relation to previous legislation, but nothing of that directly refers to a text of foreign law. The main innovations were also emphasized in the explanatory statement: (i) the option of maintaining the police investigation procedure, instead of adopting the magistrates investigation established by 1936 project; (ii) preservation of the separation between civil and criminal action; (iii) the possibility of the judge produce evidence for prosecution and defense, when the facts haven't been clarified, and may ask the defendant any questions within the limits of nemo tenetur se detegere; (iv) the possibility of judge prevents the parties from producing pieces of evidence when he finds it convenient; (v) the hearing of witnesses presided over

\footnotetext{
This project was discussed by the 13th Legislative Subcommittee, which was supposed to legislate on the "criminal process of the Federal District and Federal Justice", including police process, under Decree 19.684/1931. This commission was formed initially by Milcíades Mário de Sá Freire, Astolfo Vieira de Rezende, Cândido de Oliveira Filho, later Nelson Hungria, Vicente Piragibe and Edgard Costa participated. (VALLE, 2018, p. 41-42).
} 
and mediated by the judge, who may reject the questions asked by the parties; (vi) the increasing of the hypotheses of fictional flagrante delicto; (vii) the compulsory pre-trial detention during the criminal procedure in cases of crimes with maximum sentence equal to or greater than 10 years of imprisonment; (viii) the bench warrant for the defendant who didn't appear for his interrogation; (ix) the possibility of a new legal classification of the fact contained in the accusation by the judge before trial, when there is an error (emendation libelli) or some new evidence modify the fact narrated in the charge (mutation libelli), and ( $\mathrm{x}$ ) the simplification of the nullities system, obligating the parties and the judge to demonstrate the damage to the prosecution or defense. (CAmpos, 1941)

Despite the procedural innovations, even after the enforcing of the new law, between 1941 and 1945, the jurists restrict themselves to publishing some comments on the Code of Criminal Procedure in the Revista Forense and in the Revista dos Tribunais, but without any relevant criticism or any reference to eventual authoritarian influence from the fascist Italian legislation 1930.

It's known that the Rocco Code and Napoleonic Code represented models of modern procedural techniques and one can imagine their influence in the European-continental tradition legislation in the first half of the twentieth century. However, the jurists responsible for produce the Criminal Procedure Code of 1941 always said that the goal was make a legislation that would answer national needs, "tailored for Brazil.",

In a 1957 text, published in the Revista da Faculdade de Direito da USP, Joaquim de Almeida Canuto made comparisons between Brazilian and the Italian one, but not once did he state that the Italian

\footnotetext{
8 "It isn't the new code a new outfit made under the model of Rome or Paris, with which any mannequin can be adorned. One can clearly see from the set of its norms that is a Brazilian work, tailored for Brazil. You will undoubtedly have imperfections; but one only requires for perfection when he doesn't know life is.” (ABREU, 1942, p. 337)
} 
legislation served as an inspiration to the Code of 1941. So much so that in certain part of the text, in commenting on the thought of Italian, Eugenio Florian, he pointed out: "It should be noted that the eminent Italian professor aspires to Italy the innovations of the last two Constitution and the current Code of Criminal Procedure accomplished in the Brazilian jury proceedings: the adversarial preparatory criminal instruction, through the contrariety in the summary of guilt." (Almeida, 1957).

By the 1960s, the 1941 legislation already seemed outdated and criticisms began to appear in legal literature, but without attributing authoritarianism to it stemming from the influence of foreign laws. José Frederico Marques, an important procedure specialist of that time, argued that "The promulgation of Criminal Procedure Code was a disappointment. (...) An outdated code, without any systematization, comes to light, which was nothing more than a new edition of the obsolete local codes that had been in force before." (MARQues, 1961, p 126).

The comparison of the Brazilian criminal procedure with the Italian fascist one appeared rarely in inflamed speeches by lawyers, but without any documentary support or direct reference to Italian legislation, as seen in the Opinion of a Federal Congressman, João Mendes, on September 12, 1961, in the Committee on Constitution and Justice, as rapporteur of Bill n. 3.006/61, which revoked art. 312 of the Criminal Procedure Code. In this document, the deputy and lawyer, stated that the compulsory pre-trial detention for crime with a maximum sentence equal or superior to 10 years "was a legal aberration only explicable in legislations edited in moments of collapse of democratic life - 'the New State' -, as the current Criminal Procedure Code, which sought inspiration for the compulsory pre-trial detention in criminal the procedure law of the fascist state of Mussolini." (Mendes, 1961). It seems that this criticism only gave the eloquence to his defense of the law project, but it was isolated and did not disseminate during the period of military dictatorship in Brazil (19641985) (SKIDMORE, 1988). 
Finally, anyone that is interested to approach of the theme of foreign influences in the Brazilian criminal procedure of the 1940s, shouldn't forget to consider that Brazilian jurists in the area of criminal law had contact with the Spanish and the Latin Americans specialists, mainly with the Argentines, since Luis Jiménez de Asúa (1929), important jurist of the twentieth century, who was Spanish, but exiled in Argentina, where he formed an important network. However, this is still an unexplored field for Brazilian law historians.

\section{THE CRITICAL DISCOURSES ON AUTHORITARIANISM OF THE BRAZILIAN CODE OF CRIMINAL PROCEDURE SINCE THE $1990 \mathrm{~S}$}

With the end of the military dictatorship, Brazil initiated a deep process of revision and construction a new democratic identity of institutions. The National Constitution Assembly (1987-1988) innovate in many ways, first of all in the procedural plan, because didn't start with a pre-written text, instead worked in a gradual composition of a project in eight thematic Committee, and secondly, it had the direct participation of society, through public hearings and popular amendments, opening space for debates and confrontations between different interlocutors of opposite tendencies. (PAIXÃo, 2011, p. 164-165)

When the new Constitution came into force on October 5, 1988, emerge the necessity for a large review of the current legislation of the military dictatorship, incompatible with the new constitutional rights. The review was carried out by the judiciary, which declared the unconstitutionality of the current laws not received by the new constitutional order, as by the legislative power that promulgated several laws to regulate the new constitutional matters and revoked those in force during the dictatorial period.

Law Scholars, in their critical discourses, also claimed the constitutionalization of Brazilian law, proposing numerous methods for 
a constitutional interpretation of the current legislation ${ }^{9}$. However, criminal procedure law resisted this process of constitutionalization, and the several procedure rights have not been assured on day-to-day Courts. See, for example, the guarantee of not self-incriminate and the presence of a lawyer in the judicial interrogation, provided in art. 5, Constitution, which only registered in the Criminal Procedure Code through Law n. 10.792, dated December 1, 2003, and the right of the defender to have access to police investigation reports was assured by the Precedent 14, of the Federal Supreme Court in the judgment of February 2, 2006 and later was object of Law n. 13.245 of January 12, 2016.

Criticism of the lack of constitutionalization of criminal procedure law was made by lawyers, prosecutors and judges tired of violations of procedure guarantees perpetrated by judiciary and practices, similar to militancy and spread through strong speeches. Became common in these discourses the description of the Brazilian Criminal Procedure as authoritarian, comparing it with medieval inquisition, what was analyzed by this author in other text (BORGES, 2013), and stating that the Commission that wrote the Brazilian Code made a poor copy of the Italian fascist legislation.

The rupture that made an uniformization of critical discourse around the argument that the Brazilian Code was authoritarian because was inspired in Rocco Code began in the 90s and intensified in the next decade.

The oldest reference in the period after the military dictatorship to this positioning is an Opinion by the lawyer Jacinto Nelson de Miranda Coutinho ${ }^{10}$ requested by the President of the Subsection of the Brazilian Bar Association in Pato Branco - PR, on the police

\footnotetext{
9 On constitutionalisation of infraconstitutional law see: TEPEDINO, 1991; CATTONI, 2001, TORRES, 2005, among others.

10 Curriculum lattes of Jacinto Nelson de Miranda Coutinho. Available on 04.02.2019, at 2:30 pm: http://lattes.cnpq.br/9618548225963480.
} 
investigation secrecy, published in the Revista Brasileira de Ciências Criminais, an important periodical in the area of Criminal Law. In this text, the author sustains that the secrecy of police investigation provided by Brazilian law came from the Rocco Code, which inspired the Commission that produced the Brazilian Code of Criminal Procedure, 1941'11. A few years later, in a lecture at the II Brazilian Congress of Civil Procedure, Criminal and Courts, in Santa Catarina, in 2001, which was published in the Informative of the Faculty of Law of Coimbra (Portugal), he insisted on the same idea that this Code would be based on Rocco Code (Coutinho, 2002, p. 689). Finally, in 2009, when this professor was in the Procedure Reform External Committee, of Federal Senate, he affirmed that "the current Brazilian criminal procedure system, based on the Code of 1941 (a copy of the Codice Rocco, Italy, 1930, the fascist Vincenzo Manzini in the front), is based - and it always was - the inquisitorial structure." (Coutinho, 2009, p. 109-110).

This lawyer was an important piece in the development of this critical discourse to the authoritarianism of the Brazilian penal

11 "For a Code born in the Vargas dictatorship (Decree-Law 3.689, 03.10.1941), the source could be no other than a dictatorial one. Nelson Hungria, the great, so praised for his work, knew this. As a member of the Committee which elaborated the Code and its most eminent member, did he seek the basis on the damn criminal? see, for all, what happened to Carlo Levi, as reported in his capolavoro: Cristo si è fermato a Eboli, 7a. ed, s/d, Einaudi, 1947. Italian Rocco Code, produced by fascism under the command of Mussolini and under the baton of Manzini who for his important services received the newly created chair of Criminal Procedural Law, in Rome University; and he is widely copied as "democrat" by several of our criminalists, unsuspecting, or 'catedráulicos', as Lyra Filho, Roberto, has conceptualized. Por que estudar direito hoje?, Brasília: Nair, 1984. The secrecy thus comes from Italy: Chiudendo i pochi spiragli aperti nel 1913 alla difesa, il codice Rocco aveva restaurato un sistema coerente: ovvio che nell'istruzione, nata da metastasi inquisitoriali, avvenga tutto in segreto; gli interessati lo sapranno alla fine, col deposito degli atti (art. 372: nel rito sommario bisogna addiritura aspettare la citazione); esclusi dalla macchina inquirente, sfoghino poli l'acume critico, se vogliono, discutendo sulle carte. (Cordero, F. Guida ... cit., Pp. 288-9). It isn't surprising that people of the excellence of Joaquim Canuto Mendes de Almeida (we have to read our old men of principles) has been left out of the Commission that engendered our current Code." (COUTINHO, 1997, p.130) 
process. In 1987, he defended his master's dissertation in the Postgraduate Program in Law of the Federal University of Paraná, entitled "Notes about the lide and the content of criminal procedure". (Coutinho, 1989). This work had many Italian authors references, that was common in Brazil when you wrote about theory of procedure. However, the comparison between the Brazilian Criminal Procedure and the Italian fascist one began to gain strength after this professor's doctorate in the Universitá degli Studi di Roma, La Sapienza, in 1988.

From this moment, he formed his contact networks, supervised master's dissertations and doctoral theses, and the critical discourse, which defended that the Brazilian Criminal Procedure Code of 1941 was a copy of the Rocco Code spread and was repeated in the critical texts of the author who wrote about criminal procedure.

From this moment, relevant authors in the Brazilian legal scene began to reproduce this discourse in their academic circles, see for all Geraldo Luiz Mascarenhas Prado, judge of the Rio de Janeiro Court of Justice until 2012, and professor at the Federal University of Rio de Janeiro since 2004 ${ }^{12}$. In his master's dissertation, entitled "Accusatory System: criminal procedure laws and their conformity with the Constitution after 1998", defended in 1998 and published the follow year, he said that

the focus on the power of definition the crime attributed to the defendant and the treatment of the matter by the Brazilian Code of Criminal Procedure of 1941, inspired by the Rocco Code, demonstrate that the manipulation of the procedural functions to assign to the judge the activity of the accuser, with independent management of evidence, incorporated the criminal policy of inquisitorial (PrADO, 2005, p. 239).

12 Curriculum lattes Geraldo Luiz Mascarenhas Prado. Available on 05.02.2019, at 2 pm: http://lattes.cnpq.br/0340918656718376. 
In Rio Grande do Sul, professor and Judge Nereu José Giacomolli ${ }^{13}$, in his text published in 2015, stated: "the inquisitorial profile of the Brazilian criminal procedural model finds ideological ambiance in the 1940s, which in turn reflects the European ideology of the 1930s. The CPP was created in the middle of the New State dictatorship, with a strong influence of the fascist-inspired Italian Rocco Code." (Giacomolli, 2015) Also, in Rio Grande do Sul, the lawyer and professor Aury Lopes $\mathrm{Jr}^{14}$, commenting the explanatory statement of the current Criminal Procedure Code, said that "the authoritarian and assumed fascist inspiration (Rocco Code) - in the purest style of law and order, we would say today - is mistaken (time demonstrated this), and absolutely incompatible with the Constitutional Democratic State" (Lopes JR., 2006)

Salo de Carvalho ${ }^{15}$ who has been a lawyer and professor in Rio Grande do Sul and is currently in Rio de Janeiro since 2014, advocating and teaching at UFRJ, in his text on criminal law reforms, wrote that the current Code of Criminal Procedure

was marked by the sign of the efficiency of criminal repression. This was clearly authoritarian, because it was inspired by the reform of the Italian Criminal Procedure Code by Rocco (Mussolini's Minister of Justice), and the codified legislation chose minimizing fundamental rights and guarantees, adopting a clearly inquisitorial procedural model (CARVALHO, 2005, p. 84).

In São Paulo, Maurício Zanoide de Moraes ${ }^{16}$, a lawyer and professor at the State University of São Paulo (USP), in an interview made

13 Curriculum Lattes Nereu José Giacomolli. Available on 05.02.2019, at 3 pm: http:// lattes.cnpq.br/5969235847033808.

14 Currículo lattes Aury Celso Lima Lopes Jr. Available on 05.02.2019, at 3:40 pm: http:// lattes.cnpq.br/4629371641091359.

15 Currículo lattes Salo de Carvalho. Available on 05.02.2019 at 5:30 pm: http://lattes. cnpq.br/4997752549394373.

16 Currículo lattes Maurício Zanoide de Moraes. Available on 09.02.2019, at 10 am: http:// lattes.cnpq.br/4148561632131113. 
in 2007 to a popular legal newsletter, said that the "Code of Criminal Procedure, promulgated in 1941, was written with fascist inspiration. It is almost a copy of the Italian Penal Code, known as the Rocco Code, which was made during the rule of Benito Mussolini in 1930. The Brazilian Code served to give operationality to an inquisitorial system, preferred by authoritarian regimes." (MORAES, 2007).

A search in Google Scholar, the only indexer for scientific law journals in Brazil, demonstrate that the comparison between the Brazilian Criminal Procedure Code of 1941 and the Rocco Code of 1930 spread intensely in academic discourse in the 21 st century. Using the advanced search tool, to search for the texts that appear the words copy + poor + code + rocco, you will find 71 results $^{17}$, when you search the words fascist + procedure + criminal + code + rocco + jacinto + coutinho, 76 are the results found ${ }^{18}$, between 2005 and 2013, these years represented the time before the important change in the Brazilian criminal process with the adoption of negotiated justice on large scale. However, if the period analyzed was 1996 to 2018, the parameters fascist + procedure + criminal + code + rocco + jacinto + coutinho, 158 are the results found. ${ }^{19}$

The problem is that this direct relationship between the Brazilian and Italian legislations was established by the criminal procedural scholars without support in historical sources, even when they asserted that the Brazilian Criminal Procedure Code of 1941 is a poor copy of the Rocco Code there was no reference to documents,

\footnotetext{
17 Research done on February 7, 2019, at 6 pm: https://scholar.google.com/scholar? $\mathrm{q}=\mathrm{c} \% \mathrm{C} 3 \% \mathrm{~B} 3 \mathrm{pia}+$ malfeita $+\mathrm{c} \% \mathrm{C} 3 \% \mathrm{~B} 3$ digo + rocco\&hl $=$ pt-BR\&as_sdt $=0 \% 2 \mathrm{C} 5 \&$ as_ ylo=2005\&as_yhi $=2013$.

18 Research done on February 7th, 2019, at 6 pm: https://scholar. google.com/scholar?hl=pt-BR\&as_sdt $=0 \% 2 \mathrm{C} 5 \&$ as_ylo $=2005 \&$ as _ yhi $=2013 \& \mathrm{q}=$ fascista + processo + penal $+\mathrm{c} \% \mathrm{C} 3 \% \mathrm{~B} 3$ digo + rocco + jacinto + coutinho $\&$ btnG $=$.

19 Research done on February 7, 2019, at 6:15 pm: https://scholar.google.com/scholar?q $=$ fascista + processo + penal $+\mathrm{c} \% \mathrm{C} 3 \% \mathrm{~B} 3$ digo + rocco + jacinto + coutinho $\& \mathrm{hl}=$ pt-BR\&as_ sdt $=0 \% 2 C 5 \&$ as_ylo=1996\&as_yhi $=2018$.
} 
historiographical texts, it was a phrase of effect with the objective of convincing the reader about the harmful authoritarianism of the Brazilian criminal process.

This lack of documentary support and the emphatic tone of these critical speeches, which have no epistemological care, suggest that the adoption of historical references serves only to give them authority effects in the politic struggle against the authoritarian judicial practices on day-to-day Courts (Siqueira, 2016). The lack of serious historiographic research on the Brazilian State and society at the time of drafting of the Criminal Procedure Code of 1941, besides the blind repetition of a comparison with Italian fascist legislation, leads such critical discourses to conclude in anachronistic form so that the reasons for authoritarianism of Brazilian judicial practices of the 21st century are the same as Vargas period, which imposes significant obstacles to reflect on proposed solutions to the violations perpetrated in the current Brazilian Criminal procedure.

\section{HISTORIOGRAPHICAL INFLECTIONS ON THE DISCOURSES CRITICAL TO THE AUTHORITARIANISM OF THE BRAZILIAN CRIMINAL PROCEDURE}

The simple comparison between the original texts of the Rocco Code and the Brazilian Code of Criminal Procedure deconstructs the argument that this is a copy of that. The Brazilian criminal procedure of 1941 had peculiarities unthinkable by the Italian legislator, such as the "inquérito policial", as police procedure for produce necessary evidence to justify the accusation, without judge and prosecutor intervention; the jury's court composed only of lay jurors for the trial against life, very different of Cour d'assises; and the role of the Public Prosecutor, which was not bound by the Judiciary Power at that time.

Moreover, even if hypothetically the Italian law had been copied by Commission which drafted the Brazilian Code or it had served of 
inspiration, local judicial practices in charge of applying this legislation would be unique, would produce own reflexes and wouldn't reproduce Italian practices, which could be studied in a microhistory (GINZBURG, 1991) or history of judicial practices. In this sense, Florêncio de Abreu, one of the members in 1941 Committee, explained in his text

the Codes, since their promulgation, have freed themselves from their authors; acquired their own autonomous life. To you, your applicators, the task of printing the texts sense, life vibration, clarifying them darks, filling them gaps, flattening them imperfections (Abreu, 1943, p. 11).

This is because the law is not limited to statutory provisions or the academic comments in Compendiums but is mainly the result of the constant activity of the practices who applicates it. Therefore, the authoritarianism attributed to the current Brazilian criminal procedure is produced of oppressive judicial practices that have place in contemporary society and it is not an inheritance of fascist Italy bequeathed by the Getúlio Vargas government.

It is possible to say that Brazilian society was agitated by movements and fascist ideas in the period from 1930 to 1945 but this doesn't identify exactly with the moment of Italian society in 1919 to 1945, when there was a political power as that headed by Mussolini and it became the ideological official basis of the dictatorial regime established in Italy by him.

According to Roger Griffin, who tried minimally defines the term that became of common use to designate any authoritarian government or political action, the fascism generic can be defined as "fascism is a genus of political ideology whose mythic core in its various permutations is a palingenetic of populist ultra-nationalism." (GRIFFIN, 1991, p. 26) In other words, fascism can be portrayed as a social-political force that makes the national community reborn, after a period of decadence, for the construction of a new society founded on ancient cultural achievements, but not in the sense of 
literal restoration of the past, but of rhetorical reconstruction of the past as a healthy period of national history.

Considering this definition, he says that in Brazil, the practices of fundamentalist Integralist movement, which had grown remarkably in the 1930s and supported Vargas in his rise to the presidency, carried the characteristics of ideal type of fascism. However, for the British Historian, as opposed to critical discourses on authoritarianism of the Brazilian criminal procedure, the New State of Vargas did not fill the conditions of the ideal type of fascism, but only managed to plagiarize the Portuguese regime in its antifascism. It was at most an adulterated fascism, in which the populist forces were excited more by a charismatic dictatorship than by a vision of organic national community under a radically new order and the few ultranationalist movements were crushed by a non-revolutionary authoritarian law, as happened with Integralist action that was extinguished by Getúlio Vargas at the beginning of the New State. (Griffin, 2006, p 148)

Similarly, Robert Paxton in his book entitled the «The anatomy of fascism», concludes that

like Salazar in Portugal, far from governing through a fascist party, Vargas closed down the Integralists and the pro-Nazi and pro-Fascist movements along with all other parties. Vargas, a slight man who disliked public speaking and admitted that riding a horse hurt his backside, failed to rise even to the gaucho image of his home state of Rio Grande do Sul, much less to that of a fascist jefe (PAxton, 2004, p.193).

This means that according to this view wouldn't be possible to say that the Brazilian Criminal Procedure Code of 1941 was the result of a fascist government. However, Elizabeth Cancelli disagrees and asserts that Getúlio Vargas shaped a generic fascism, since the New state had a mythical core of nation rebirth towards modernity, encouraging ultranationalism, socio-political corporatism, and presenting itself to the nation as a great leader. (CANCELLI, p. 162). In this sense, was the statement of the lawyer Victor Hugo Baldessarini, after the 
end of New State, complaining of the incompatibility of the Criminal Procedure Code with the Constitution of 1941: "which may seem absurd, but in fact, is easy to understand, it is the positive mismatch between the democratic Constitution of 1946 and the earlier fascist ordinary laws." (BALDESSARINI, 1947, p. 335)

Anyway, even if an author understands that the Vargas government was fascist and the legislation produced in the period of New State incorporated the political nationalist ideology, he couldn't say that the Brazilian Criminal Procedure Code of 1941 copied the Rocco Code or was inspired by it, even because the idea of valuing what was national would be contrary to copy a foreign legislation. In this regard, Florencio de Abreu, a member of the Committee which produced the Brazilian Criminal Code and Procedure Code, ensured that both deeply rooted in the juridical conscience of nationality. (ABReu, 1943, p. 5). Therefore, defend that Brazilian Criminal procedural law is authoritarian because copied from Italian fascists doesn't go beyond the field of speculation.

The fact that the Minister of Justice, Francisco Campos, made reference to Alfredo Rocco in the Explanatory of the Criminal Procedure Code of 1941, does not allow to conclude that there was a fascist inspiration for the jurists who were part of the Committee ${ }^{20}$. Besides this, no one knows if the Minister effectively participate in the producing work of the Brazilian Criminal Procedure Code, since there is no mention of any meetings of the Commission with the Minister in the newspaper of that time, on the contrary of the other Codes elaborated in Vargas government.

20 "At the time of the last reform of the criminal procedure in Italy, Minister Rocco, referring to some of these and similar measures introduced in the preliminary draft, warned that they would certainly provoke the displeasure of those who were accustomed to seize and even abuse the inveterate deficiencies and weaknesses of the criminal procedural until in force. The same prediction can be made in relation to this project, but also to repeat the words of Rocco: "The time has already passed when the bustling coalition of a few interested parties could frustrate the most correct and urgent legislative reforms." (CAMPOS, 1941, P. 628) 
On the other hand, it would be possible to think about an alignment between Brazilian Criminal Procedure law and the fascist Italian, due to the circulation of a technicist legal culture among Brazilian jurists and Italian, including this phenomenon was in detail analyzed by Brazilian (Sontag, 2009; Fernandes, 2015) and Italian (Sbriccoli, 2009) historians of law when they wrote about the Criminal Code. However, once again there is a lack of sources that prevent from the verification of this circulation and its influence on the elaboration of Criminal Procedure Code.

Indeed, at this point may be the key to understanding affirmations that identify the Brazilian Criminal Procedure Code and the Rocco Code, even because the autonomy of criminal procedural law in relation to criminal law was late recognized by most Brazilian jurists. The first author to write about institutes of criminal procedure was José António Pimenta Bueno São Vicente, in his book "Notes on the Brazilian criminal procedure" (1857), also during the Brazil-Empire (1822-1889), and the second of equal importance was João Mendes de Almeida Júnior, who published in 1900, the first volume of his work "Brazilian Criminal Procedure" (Almeida JR., 1900). Therefore, for a long time in Brazil the criminal procedural law was studied as an accessory to criminal law, as an adjective law dependent on substantive law, which always relegated to a second place. This was reflected in the indication of the Committee that drafted the Criminal Procedural Code, composed of recognized criminal law scholars such as Nelson Hungria and Roberto Lyra, responsible for drafting the Criminal Code and no one specializes in criminal procedure. As mentioned, much has already been studied about the legal culture that circulated between the Brazilian and Italian criminalists in the 1930s and 1940s and their influence on the criminal legislations of these countries, but nothing was specifically referred about the criminal procedure, which is a strong clue that criminal procedural law occupied a place without relevance in academic studies and was seen as a simply attached to criminal law. 
A Brazilian criminal procedural law scholar, Ricardo Gloeckner, attempted to demonstrate this circulation of ideas among Italian criminalists punctuating the changes imposed by the Rocco Code and comparing them with the changes introduced by the Code of 1941 in Brazilian criminal procedure. Although, in his text there was no direct reference to the Italian legislation, he mentioned mainly the books and articles that comment on the circulation of a technicist legal culture between Brazilians and Italians at the beginning of the last century and as well as its influence in the conception of the Criminal Codes without warning that there are no sources that can prove influence in the drafting of Brazilian Criminal Procedure Code.

Treating specifically with criminal procedure, he made a comparison between the changes established by the Brazilian Code of 1941 and the Rocco Code based on comments from Italian and Brazilian law scholars of that time, seeking to find at all costs, identification on the basis of the procedure principles of both countries. His text contains dangerous categorical statements on the work of the Commission that elaborated Brazilian legislation, like the one he did about compulsory pre-trial detention in the Criminal Procedure Code of 1941: "just as in Italy, the Committee introduced this kind of compulsory pre-trial detention without to speak of the spectrum extension of its hypothesis and the reduction of provisional liberty. (GLOECKNER, 2018, p. 402)

It seems that this forced observation didn't consider that the French Code d'instruction Criminelle of 1808 (FrANCE, 1808) already prohibited bail for crimes with distressing and disgraceful punishments ${ }^{21}$ and authorized the investigating magistrate to order the arrest even before the indictment was formulated. ${ }^{22}$

21 Article 113 La liberté provisoire ne pourra jamais accordée au prévenu lorsque le titre de l'accusation emportera une peine afflictive ou infamant.

22 Article 94 Il pourra, après avoir entendu les prévenus, et le procureur impérial ouï, décerner, lorsque le fait emportera peine afflictive ou infamante ou emprisonnement correctionnel, un mandat d'arrêt dans la forme qui sera ci-après prescrite. 
In synthesis, it is seen that this author makes a great effort to support the affirmation that the 1941 Criminal Procedure Code was inspired by the fascist Code of Criminal Procedure, making it clear that this supposed influence persists today and contributes to the authoritarianism of the Brazilian criminal procedure, including in the decisions of the Federal Supreme Court (Gloeckner, 2018, p. 463). This objective was clear at the beginning of the text, when he admitted that the statement of the critical discourse that Brazilian criminal procedural law was a copy of the Fascist Code is a "lethargic mantra", but he ensured that this diagnosis is correct, creating an insoluble paradox:

This task was performed so that the work wouldn't fall into a kind of lethargic mantra (though correct in its diagnosis and warning) that our Code is a 'copy' of the Italian Code of Criminal of 1930. It isn't a copy. That is a similar legislation in all the central issues, which in fact makes difficult a purely structural analysis between the articles (even by the different proceedings, by the regulation of the matter in distinct books, according to a sequence also, not identical). Even assuming the diversity of codes in their style (the Italian procedure keeping the model named 'mixed', and the Brazilian juxtaposing various procedural categories without separating of the Portuguese tradition - clear example of this is the maintenance of the police investigation, from the Brazil Empire), the Brazilian Code of Criminal Procedure clearly inspired by the work of MANZINI, the intellectual in charge of the elaboration of the project (GLOECKNER, 2018, p. 36).

This dedication to fit the study he made of the ideas that supposed circulated among Brazilian criminalists during the elaboration of the Criminal Procedure Code of 1941 into the affirmation of the critical discourses that attribute the authoritarianism of the current Brazilian criminal procedure to an inheritance of the fascist legislation of 1930, is probably a consequence of what Airton Seelaender named 'socialization courts' that are big support networks 
to produce self-justifications of high literary quality to professors resistant to the new theories. Thus, networks formed by assistants, master students, doctoral students, collaborators, ex-collaborators, who must defend the old to prevent the questioning their own academic "pedigree". Collective defense, loyalty, and solidarity strengthen ties, broaden reciprocal support, and increase the effectiveness of socialization courts in which these scholars participate (Seelaender, 2009, p. 416).

It should be noted that Ricardo Jacobsen Gloeckner ${ }^{23}$ is a professor at PUC-RS and a lawyer in the Rio Grande do Sul, his doctoral advisor was Jacinto Nelson de Miranda Coutinho, his master advisor was Aury Lopes Jr. His book, entitled “Authoritarianism and Criminal Procedure: a genealogy of authoritarian ideas in Brazilian criminal procedure", was prefaced by Geraldo Prado and Jacinto Nelson de Miranda Coutinho, responsible for spreading the idea that Brazilian Criminal Procedure Code is authoritarian because it is inspired by fascist legislation.

This attachment of the critical discourse to the authoritarianism of the Brazilian penal process to a mythical origin, of which the Criminal Procedure Code of 1941 is a copy of the Rocco Code, pushes the criminal procedural law scholars to an unavoidable anachronism, which attributes to the past legislation a fascism that is typical of current judicial practices and not because associated justices of Brazilian Federal Supreme Court simply apply a Criminal Procedure Code copied from the Rocco Code, as Ricardo Gloeckner defends. Therefore, this critical discourse judges the past denying the impressions of the members of Committee who elaborated the Code of 1941. Roberto Lyra one of those members commented the compulsory pre-trial detention provided in this legislation and said: "What deserved my support cannot be fascist." (Lyra, 1977, p. 68).

23 Currículo lattes Ricardo Jacobsen Gloeckner. Available on 09.02.2019, at 3:40 pm: http://lattes.cnpq.br/2085174043653648. 
On the other hand despite the justification for the defense of the old was the emphatic tone of the argument the fascist origin of Brazilian criminal procedural law, it must be recognized that such a strategy of the critical discourse on authoritarianism of Brazilian legislation hasn't been effective for to prevent from the growing violation of rights and guarantees in the Brazilian criminal procedure, as well as its use to criminalize political groups.

Instead, the repetition of this thesis has prevented the authors perceive the Brazilian criminal procedure law isn't the same as in 1941, because that numerous Code reforms and the edition of extravagant laws distanced it from the original wording on important topics such as the negotiated criminal justice system (Law n. 9.999/95 and Law n. 12.850/13), the citation (Law n. 9.271/96), the interrogation of the defendant (Law n. 10.792/03), the jury (Law n. 11.689/09), the evidence (Law n. 11.690/08), the proceedings (Law no. 11.719/08), detention and bail (Law n. 12.403/11), the scientific evidence, preliminary investigation, precautionary measures (Law n. 13.964/19), among others.

For some time the legislative changes have shown that the criminal prosecution steps towards generalized adoption of American bargains, the guilty plea was provided in our legislation since 1990 (Law n. 8.072), but it was little studied subject, until the moment that this evidentiary procedure has been used widely in media impact procedures and to criminalize political groups, as was the "Mensalão" scandal (JefFerson, 2005) in which Brazilian parliamentarians and members of the executive branch were convicted of participating in a scheme to sell votes, and in the case of "Operation Car-Wash" (FOLHA DE SÃo Paulo, 2014), in which members of the Parliament and the Executive power, buildings contractors, managers of state companies are being accused of involvement in a major corruption scheme in the execution of public works.

For many years, some of the procedural law scholars responsible for the diffusion of critical discourses refused discuss about the forms to ensures the guarantees in guilty plea under the argument that 
criminal negotiated justice does not integrate the adversarial procedure model neither can be considerate as a requirement of the criminal procedural that has parties because it results in a dangerous alternative to procedure and bury a lot of guarantees obtained over centuries of injustice (LOPES JR., 2001, p. 27).

This refusal to reflect on new institutes of criminal procedural law, which were imported from foreign legislations other than Italian law, can be verify by research in Google Scholar, where one can observe the increase in written texts on the subject of the guilty plea in the last 5 years, that is, 15 years after the legislation that introduced it in the Brazilian Criminal Procedural Law and since the beginning of "Operation Car Wash". Thus, it's possible to identify in a Google Scholar research 1.388 results in the period between 2014 and 201924, for the parameters guilty+plea; in the period between 2001 to 2013, 640 results 25 , and in the period 1990 to 200026, just 36 results.

In fact, the defense of the old critical discourse resisted historiographical research for many years and may have prevented the Brazilian criminal procedural law scholars from realizing the tendencies of change in criminal procedural forms and preparing strategies to effect guarantees for the defendants in this scenario. If we had recognized earlier that the Brazilian criminal procedural legislation has suffered several foreign influences in the last decades, including American, it would have been possible to think of strategies to conform them to the constitutional order, preventing for example that people be

24 Research done on February 10, 2019, at 9:50 am: https://scholar.google.com/ scholar?q=dela $\% \mathrm{C} 3 \% \mathrm{~A} 3 \mathrm{o} \% \mathrm{C} 3 \% \mathrm{~A} 3 \mathrm{o}+$ premiada\&hl $=$ en-US \& as_sdt $=0 \% 2 \mathrm{C} 5 \&$ as_ylo $=2014 \&$ as_yhi $=2019$.

25 Resarch done on February 10, 2019, at 10 am: https://scholar.google.com/ scholar?q=dela $\% \mathrm{C} 3 \% \mathrm{~A} 3 \mathrm{o}+$ colabora $\% \mathrm{C} 3 \% \mathrm{~A} 3 \mathrm{o}+$ premiada\&hl $=$ en-US \& as_sdt $=0 \%$ 2C5 \& as_ylo $=2001 \&$ as_yhi $=2013$.

26 Research done on February 10, 2019, at 10:05 am: https://scholar.google.com/ scholar?q=dela $\% \mathrm{C} 3 \% \mathrm{~A} 3 \mathrm{o} \% \mathrm{C} 3 \% \mathrm{~A} 3 \mathrm{o}+$ premiada\&hl $=$ en-US \& as_sdt $=0 \% 2 \mathrm{C} 5 \&$ as_ylo $=1990 \&$ as_yhi $=2000$. 
condemned essentially with guilty plea pieces of evidences, as it occurred in the case of the ex-President Lula's sentence, which prevented him from running again in the 2018 elections in an evident political use of the criminal process 27 . Indeed, it is necessary to emphasize that the most recent studies on Brazilian criminal procedural law have been moving in this direction, and significant advances have been made in the discussions about the defendant's rights in plea bargains (VAsCONCEllos, 2017).

\section{FINAL CONSIDERATIONS}

Until now, this research analyzed the critical discourses that attribute the authoritarianism of the current Brazilian criminal procedure to Italian fascist legacy that would be transmitted, when jurists who were members of the Committee copied or were inspired by the Rocco Code in the elaboration of the Brazilian Criminal Procedure Code of 1941. Thus, considering the care that a historiographic analysis requires, it has been demonstrated that such a direct link between the two legislations cannot be established, since there are no historical sources to support this reasoning.

In addition, it was pointed that if it were possible to demonstrate the inspiration of the Brazilian criminal procedural law in the Rocco Code, still a study of Brazilian judicial practices would be necessary to verify how the application of this legislation occurred in concrete cases, in accordance with needs and desires of the Brazilian society of the time through a study from micro-history or history of judicial practices.

\footnotetext{
BRAZIL. Sentence. Federal Criminal Justice of Curitiba. Judiciary Section of Paraná. Case files n. 5046512 - 94.2016. 4.04.7000/ PR. Juiz Sérgio Fernando Moro, Curitiba, Paraná, July 12, 2017. Available on 10.02.2019, at 10 pm: http://www.mpf.mp.br/parao-cidadao/caso-lava-jato/atuacao-na-1a-instancia/denuncias-do-mpf/documentos/ LulaSENT1.pdf/view.
} 
It has also been shown that the many reforms undergone by Brazilian criminal procedural law over the 78 years of the Code of Criminal Procedure prohibit criminal procedural law scholars from asserting that the Brazilian criminal procedure of the 21st century is authoritarian because it is regulated by a fascist legislation of 1941.

Finally, we analyze how the discourse that attributes the authoritarianism of the Brazilian penal process to an inheritance of the Rocco Code diffused intensely in Brazil from the 1990s and how it prevented procedural law scholars from perceiving the influence of other foreign legislations in the criminal procedure and preparing themselves to understand the new procedural institutes, as guilty plea, which would gain large application in judicial practices.

However, this phase of the research is still under development, since it intends to demonstrate through a deeper study of the critical discourses of its protagonists in order to understand how this inadequate appropriation of the history of the Criminal Procedure Code of 1941 had effects on the judicial practices in cases involving procedural institutes imported from foreign legislations, in academic studies on Brazilian criminal procedure and discussions of future reforms of the Criminal Procedure Code.

\section{REFERENCES}

ABReU, F. Princípios informativos do Código de Processo Penal. Revista Forense, Rio de Janeiro, v. XCVI, a. XL, fasc. 424, out. p. 5-11, 1943. ALMEIDA, J. C. M. de. O princípio da verdade real. Revista Da Faculdade De Direito, Universidade de São Paulo, v. 52, 1957, pp. 116-138. Available on 04.02.2019, at $4 \mathrm{pm}$ : https://www.revistas.usp.br/rfdusp/ article/view/66266.

ALMEIDA JR., J. M. de. Processo criminal brazileiro. Rio de Janeiro: Laemmert, vol. I, 1900. 
ASÚA, L. J.. Un viaje al Brasil: impresiones de um conferenciante, seguidas del um estúdio sobre el derecho penal brasileño. Madrid: Reus, 1929.

BALDESSARINI, V. H.. O relaxamento da prisão e o $\ 22$ do art. 141 da Constituição Federal. Revista Forense, Rio de Janeiro, v. CXII, a. XLIV, fasc. 529, jul., 1947, pp. 333-335.

BORGES, C. M. R.. Um olhar para além dos sistemas processuais penais. Revista Brasileira de Ciências Criminais. Vol. 21, n. 104, 2013, pp. 147-171.

CAMPOS, F.. Exposição de motivos do Código de Processo Penal. Revista Forense, Rio de Janeiro, v. LXXXVIII, a. XXXVIII, fasc. 462, dez.,1941, pp. 627-636.

CANCELLI, E.. When law and prerogatives Blend: generic fascism in Getulio Varga's Brazil, 1930-1945. In: SKINNER, Stephen. Fascism and Criminal Law: history, theory, continuity. Oxford: Hart Publishing, 2015.

CARVALHO, S. de. As reformas parciais no processo penal brasileiro. In: CARVALHO, Amilton de; CARVALHO, Salo de. Reformas penais em debate. Rio de Janeiro: Lumen Juris, 2005.

CATTONI, M.. Direito processual constitucional. Belo Horizonte: Mandamentos, 2001.

COUTINHO, J. N. de M.. Efetividade do processo penal e golpe de cena: um problema das reformas processuais no Brasil, Boletim da Faculdade de Direito da Universidade de Coimbra, n. 78, 2002.

COUTINHO, J. N. de M.. O sigilo do inquérito policial e os advogados. Revista Brasileira de Ciências Criminais, vol. 18, abr-jun, p. 123-134, 1997.

COUTINHO, J. N. de M.. Sistema acusatório: cada parte no lugar constitucionalmente demarcado. Revista de Informação Legislativa, Senado, Brasília, a. 46, n. 183, jul.-set., p. 103-115, 2009.

FERNANDES, R. D. Pensamento criminológico na Primeira República: o Brasil em defesa da sociedade. Tese (Doutorado em Direito), Programa de Pós-graduação em Direito, Universidade Federal do Paraná, Universitá degli Studi di Firenze, Paraná, Firenze, 2015. 
FOUCAULT, M.. Nietzche, genealogy, history. In: Language, conter-memory, practice: selected essays and interviews by Michel Foucault, Ithaca: Cornell University Press, pp.139-164, 1977.

GIACOMOLLI, N.. Algumas marcas inquisitoriais do Código de Processo Penal brasileiro e a resistência às reformas. Revista Brasileira de Direito Processual Penal, São Paulo, ano I, n. 1, jan./jun. 2015, pp. 143-165.

GINZBURG, C.. A micro-história e outros ensaios. Trad. António Narino. Lisboa: Difel, 1991.

GRIFFIN, R.. The nature of fascism. New York: Routledge, 1993, v. digital 2006.

JEFFERSON, R.. Entrevista: Jefferson denuncia mesada paga pelo tesoureiro do PT. Lo Prete, Renata. Folha de São Paulo, 06.06.2005. Available on 10.02.2019, at 10 pm: Disponível em: https://www1.folha.uol.com.br/ folha/brasil/ult96u70262.shtml.

LOPES JR., A.. Sistemas de investigação preliminar. Rio de Janeiro: Lumens Juris, 2001.

LOPES JR., A.. Introdução crítica ao processo penal: fundamentos da instrumentalidade constitucional. 4. ed. Rio de Janeiro: Lumen Juris, 2006.

PAIXÃO, C.. Direito, política, autoritarismo e democracia no Brasil: da revolução de 30 à Constituição de 1988. Araucária, Revista Iberoamericana de Filosofia, Política y Humanidades, a. 13, n. 26, jul-dez, 2011, pp. 146-169. Available on 03.02.2019, at 4 pm: file://Users/claraborges/ Downloads/DialnetDireitoPoliticaAutoritarismoEDemocraciaNoBrasil-3764236\%20(2).pdf.

PAXTON, R. O.. The anatomy of fascism. New York: A. A. Knopf, 2004. PRADO, G. L. M.. Sistema acusatório: a conformidade constitucional das leis processuais penais. 3.ed. Rio de Janeiro: Lumen Juris, 2005. LYRA, R.. Código de Processo Penal de 1941. In: Direito penal normativo. 2. ed. Rio de Janeiro: José Konfino, 1977.

MARQUES, J. F.. Elementos de direito processual penal. São Paulo: Forense, vol I, 1961.

PANDOLFI, D. C.. Os anos 30: as incertezas do regime. In: Anais do XXII Simpósio Nacional de História - ANPUH, João Pessoa, 2003, pp. 1-7. 
MENDES, J.. Parecer ao Projeto de Lei no 3.066/1961. Comissão de Constituição e Justiça, Câmara dos Deputados. 12 set. 1961. Available on 10.02.2019, at 1 pm: https://www.camara.leg.br/proposicoesWeb/prop_ mostrarintegra;jsessionid=CE0C0B772C6BFA9F7E6C6EB17A250C28. node2? codteor $=1203516 \&$ filename $=$ Avulso $+-P L+3066 / 1961$.

MORAES, M. Z.. Entrevista: Maurício Zanóide de Moraes, criminalista. Cardoso, Maurício e Matsuura, Lilian, Boletim de notícias Conjur, jan. 14, 2007. Available on: 09.02.2019, at 10 am:https://www.conjur.com. br/2007jan14/direito_penal_nao_instrumento_seguranca_publica.

RÁO, Vicente; FARIA, Antonio Bento de; CASADO, Plínio de Castro. Projeto do Código de Processo Penal da República dos Estados Unidos do Brasil. Revista da Faculdade de Direito, Universidade de São Paulo, v. 34, n. 3, p. 137-292, 1938.

SÃO VICENTE, J. A. P. B.. Apontamentos sobre o processo criminal brasileiro. 2. ed. Imprenta: Rio de Janeiro, Empreza Nacional do Diario, 1857.

SBRICCOLI, M.. Le mani nella pasta e gli occhi ai cielo. La penalistica italiana negli anni del fascimo. In: Storia de diritto e della giustizia penale. Scritti e editi inediti (1972-2007). Milano: Giuffré, Tomo I, 2009.

SEELAENDER, A. C.-L.. A história do direito contemporâneo: um projeto possível?. Revista da Faculdade de Direito da UFRGS, Porto Alegre, n. 36, ago., p. 20-35, 2017.

SEELAENDER, A. C.-L.. Juristas e ditadura uma leitura brasileira. In: ; FONSECA, R. M.(Org.). História do Direito em perspectiva: do antigo regime à modernidade. Curitiba: Juruá, 2009, pp. 415-432.

SILVEIRA, G. S.. Pequeno ensaio sobre o direito ensina errado a história ou algumas dicas para quem faz um trabalho acadêmico. In: CUNHA, J. R.. Epistemologias críticas do direito. Rio de Janeiro: Lumen Juris, 2016. SILVEIRA, M. de M.. Um processo de difusão e desenvolvimento cultural excelente: a revista Direito e os periódicos jurídicos no Brasil da passagem dos anos 1930 a 1940. Anais do XXVI Simpósio Nacional de História - ANPUH, São Paulo, julho 2011. Available on 02.02.2019, at 8 pm: http://www.snh2011.anpuh.org/resources/anais/14/1308166992_ARQUIVO_TextoANPUH.pdf. 
SKIDMORE, T.. De Castelo a Tancredo (1964-1985). Trad. Mario Silviano Silva. Rio de Janeiro: Paz e Terra, 1988.

SONTAG, R.. Código e Técnica. A reforma penal brasileira de 1940, tecnicização da legislação e atitude técnica diante da lei em Nelson Hungria. Dissertação (Mestrado em Teoria e Filosofia do Direito), Programa de Pós-graduação em Direito, Universidade Federal de Santa Catarina, 2009.

TEPEDINO, M. C. B. de M.. A caminho de um direito civil constitucional. Revista Estado, Direito e Sociedade, PUC-Rio, Rio de Janeiro, vol. I, 1991, pp. 126-163. Available on 05.02.2019, at 8 pm: https://revistades. jur.puc-rio.br/index.php/revistades/article/view/352/325.

TORRES, R. L.. A segurança jurídica e as limitações constitucionais ao poder de tributar. Revista eletrônica de Direito do Estado. Salvador, Bahia, n. 4, out./nov./dez, 2006, pp. 2-18. Available on 10.02.2018, at 7 pm: https://s3.amazonaws.com/academia.edu.documents/37651098/1270839842. pdf?AWSAccessKeyId=A KI A I WOW Y YGZ2Y53UL3A\&Expires $=1549824705 \&$ Signature $={ }_{v} S 30 D 1 N 93 A m 4 v \% 2 F K G r v Z X e Z \% 2 F 2 Z I 8 \%$ 3D\&responsecontentdisposition=inline $\% 3 \mathrm{~B} \% 20$ filename $\% 3$ DPrincipios_ Subprincipios_Superlegalidade.pdf. Acesso em: 10.02.2018, às 19:00.

VALLE, G. S. do. Uma história da cultura jurídica processual penal brasileira (1930-1945). Dissertação (Mestrado em Direito do Estado), Programa de Pós-graduação em Direito, Universidade Federal do Paraná, 2018.

VASCONCELLOS, V. G. Colaboração premiada no processo penal. São Paulo: RT, 2017.

\section{Documentary references}

BRAZIL. Constitution of the Republic of the United States of Brazil, July 16, 1934. Diário Oficial da União, Rio de Janeiro, DF, Jul. 16, 1934. Available on 05.02.2019, at 8:05 pm: http://www.planalto.gov. br/ccivil_03/Constituicao/Constituicao34.htm.

BRAZIL. Constitution of the Federativ Republic of Brazil, October 5, 1988. Diário Oficial da União, Brasília, DF, Oct. 5, 1988. Available on 04.02.2019, at 8 pm: http://www.planalto.gov.br/ccivil_03/Constituicao/ Constituicao.htm. 
BRAZIL. Sentence. Federal Criminal Justice of Curitiba. Judiciary Section of Paraná. Case files n. 5046512 - 94.2016. 4.04.7000/ PR. Juiz Sérgio Fernando Moro, Curitiba, Paraná, July 12, 2017. Available on 10.02.2019, at $10 \mathrm{pm}$ : http://www.mpf.mp.br/para-o-cidadao/caso-lava-jato/atuacao-na-1a-instancia/denuncias-do-mpf/documentos/LulaSENT1.pdf/view.

BRAZIL. Law n. 38, April 4, 1935. Diário Oficial da União, Rio de Janeiro, DF, br. 1935. Available on 06.02.2109, at 8 pm: http://www2. camara.leg.br/legin/fed/lei/1930-1939/lei-38-4-abril-1935-397878-republicacao-77367-pl.html.

BRAZIL. Civil Procedure Code, September 18, 1939. Colleção das Leis da República dos Estados Unidos do Brasil de 1939. V. 7, p. 311-348, Rio de Janeiro, DF. Available on 05.02.2019, at 6:30 pm: http://www.planalto. gov.br/ccivil_03/decreto-lei/1937-1946/Del1608.htm.

BRAZIL. Criminal Code, December 7, 1940. Diário Oficial da União, Rio de Janeiro, DF, Dec. 31, 1940. Available on 05.02.2019, at 6:35 pm.: http://www.planalto.gov.br/ccivil_03/decreto-lei/Del2848compilado.htm. BRAZIL. Criminal Procedure Code, October 3, 1941. Diário Oficial da União, Rio de Janeiro, DF, Oct. 13, 1941. Available on 05.02.2019, at 6:40 pm: http://www.planalto.gov.br/ccivil_03/decreto-lei/Del3689Compilado.htm.

BRAZIL. Law n. 8.072, July 25, 1990. Diário Oficial da União, Brasília, DF, Jul. 26, 1990. Available on 10.02.2019, at 5 pm: http://www.planalto. gov.br/ccivil_03/LEIS/L8072.htm.

BRAZIL. Law n. 9.099, September 26, 1995. Diário Oficial da União, Brasília, DF Sept. 27, 1995. Available on 10.02.2019, at 5:05 pm: http:// www.planalto.gov.br/ccivil_03/LEIS/L9099.htm.

BRAZIL. Law no 12.850, August 2, 2013. Diário Oficial da União, Brasília, DF, Aug. 5, 2013. Available on 10.02.2019, at 5:15 pm: http://www. planalto.gov.br/ccivil_03/_Ato2011-2014/2013/Lei/L12850.htm.

BRAZIL. Law n. 9.271, April 17, 1996. Diário Oficial da União, Brasília, DF, Apr. 18, 1996. Available on 10.02.2019, at 5:20 pm: http://www. planalto.gov.br/ccivil_03/LEIS/L9271.htm.

BRAZIL. Law n. 10.792, December 1, 2003. Diário Oficial da União, Brasília, DF, Dec. 2, 2003. Available on 10.02.2019, at 5:25 pm: http:// www.planalto.gov.br/ccivil_03/LEIS/2003/L10.792.htm. 
BRAZIL. Law n. 11.689, June 8, 2008. Diário Oficial da União, Brasília, DF, Jun. 10, 2008 Available on 10.02.2019, at 5:40 pm: https://www2. camara.leg.br/legin/fed/lei/2008/lei-11689-9-junho-2008-576196-norma-pl.html.

BRAZIL. Law n, 11.690, June 9, 2008. Diário Oficial da União, Brasília, DF, Jun. 10, 2008. Available on 10.02.2019, at 5:30 pm: http://www.planalto. gov.br/ccivil_03/_Ato2007-2010/2008/Lei/L11690.htm.

BRAZIL. Law no 11.719, June 20, 2008. Diário Oficial da União, Brasília, DF, Jun. 23, 2008. Available on 10.02.2019, at 5:35 pm: http://www. planalto.gov.br/ccivil_03/_Ato2007-2010/2008/Lei/L11719.htm.

BRAZIL. Law n $\mathbf{n}^{\mathbf{1 2}}$ 1203, May 4, 2011. Diário Oficial da União, Brasília, DF, May 5, 2011. Available 10.02.2019, at 5:40 pm: http://www.planalto. gov.br/ccivil_03/_Ato2011-2014/2011/Lei/L12403.htm.

BRAZIL. Law no. 13.964. Dec. 21, 2019. Diário Oficial da União , Brasiliía, DF, Dec. 21. Available on 15.03.2010, at 6:38 pm: http://www. planalto.gov.br/ccivil_03/_ato2019-2022/2019/lei/L13964.htm.

BRAZIL. STF. Binding Precedent 14. 2009. Available on 11.02.2019, at 9:30 pm: http://www.stf.jus.br/portal/jurisprudencia/menuSumario. asp?sumula $=1230 \&$ termo $=$.

Code of Criminal Procedure. Signed by the President of the Republic the Decree-Law promulgating it - Summary of its devices. Jornal do Commercio, October 05, 1941. Available on 03.02.2019, at 4:35 pm: http://memoria.bn.br/DocReader/DocReader.aspx?bib=364568_13\&Pa$\mathrm{gFis}=8906 \& \mathrm{Pesq}=$ código $\% 20 \mathrm{de} \% 20$ processo $\% 20$ penal.

Currículo lattes Aury Celso Lima Lopes Jr. Available on 05.02.2019, at 3:40 pm.: http://lattes.cnpq.br/4629371641091359.

Currículo lattes Geraldo Luiz Mascarenhas Prado. Available on 05.02.2019, at 2:00 pm: http://lattes.cnpq.br/0340918656718376.

Currículo lattes de Jacinto Nelson de Miranda Coutinho. Available on 02.02.2019, at 2:30 pm: http://lattes.cnpq.br/9618548225963480

Currículo lattes Maurício Zanoide de Moraes. Available on 09.02.2019, at 10 am: http://lattes.cnpq.br/4148561632131113.

Currículo lattes Nereu José Giacomolli. Available on 05.02.2019, at 3 pm: http://lattes.cnpq.br/5969235847033808. 
Currículo lattes Ricardo Jacobsen Gloeckner. Availble on 09.02.2019, at 3:40 pm: http://lattes.cnpq.br/2085174043653648.

Currículo lattes Salo de Carvalho. Available on 05.02.2019, at 5:30 pm: http://lattes.cnpq.br/4997752549394373.

FOLHA DE SÃO PAULO. Folha Explica: Operação Lava Jato. Jornal Folha de São Paulo. 14.11.2014. Available on 11.02.2019, at 2 pm: https:// www1.folha.uol.com.br/poder/2014/11/1548049-entenda-a-operacaolavajatodapolicia-federal.shtml.

FRANCE. Code d'Instruction Criminelle. 1808. Available on 10.02.2018, at $9 \mathrm{am}$ : https://ledroitcriminel.fr/la_legislation_criminelle/anciens_textes/ code_instruction_criminelle_1808/code_instruction_criminelle_1.htm.

ITALY. Codice di Procedura Penale. Ministero della Giustizia e degli Affari di Culto. Roma: Istituto Poligrafico dello Stato Libreria, 1930.

Judicial Branch. Jornal do Commercio, October 04, 1941. Available on 03.02.2019, at 4:30 pm: http: //memoria.bn.br/DocReader/DocReader.aspx? $\mathrm{Bib}=364568 \_13 \&$ PagFis $=8906 \&$ Pesq $=$ code $\% 20$ of $\% 20$ process $\% 20$ penal. Judicial Party. Jornal do Commercio, October 7, 1941. Available on 03.02.2019, at 5 pm: http://memoria.bn.br/DocReader/DocReader.aspx?$\mathrm{bib}=364568 \_13 \& \mathrm{PagFis}=8906 \& \mathrm{Pesq}=$ code $\% 20 \mathrm{de} \% 20$ processo $\% 20$ penal.

Lawyers Institute. Jornal do Commercio, September 18, 1941. Available on 03.02.2019, at 4:00 PM: http://memoria.bn.br/DocReader/DocReader.aspx?bib $=364568 \_13 \&$ PagFis $=8906 \&$ Pesq $=$ code $\% 20 \mathrm{de} \% 20$ processo $\% 20$ penal.

Research done on February 7, 2019, at 6:15 pm: https://scholar.google.com/ scholar?hl=pt-BR\&as_sdt $=0 \% 2 \mathrm{C} 5 \&$ as_ylo $=2005 \&$ as_yhi $=2013 \& \mathrm{q}=$ fascista + processo + penal $+c \% \mathrm{C} 3 \% \mathrm{~B} 3$ digo + rocco + jacinto + coutinho $\& b \operatorname{btnG}=$.

Research done on February 7, 2019, at 6:30 pm: https://scholar.google.com/ scholar?q=fascista + processo + penal $+\mathrm{c} \% \mathrm{C} 3 \% \mathrm{~B} 3$ digo + rocco + jacinto + coutinho\&hl=pt-BR\&as_sdt=0\%2C5\&as_ylo=1996\&as_yhi=2018.

Research done on February 7, 2019, at 6:00 pm: https://scholar.google.com/ scholar?q $=\mathrm{c} \% \mathrm{C} 3 \% \mathrm{~B} 3$ pia + malfeita $+\mathrm{c} \% \mathrm{C} 3 \% \mathrm{~B} 3$ digo + rocco\&hl $=$ ptBR\&as_ sdt $=0 \% 2$ C5\&as_ylo $=2005 \&$ as_yhi $=2013$.

Research done on February 10, 2019, at 09:50 am: https://scholar.google.com/ scholar?q=dela $\% \mathrm{C} 3 \% \mathrm{~A} 7 \% \mathrm{C} 3 \% \mathrm{~A} 3 \mathrm{o}+$ colabora $\% \mathrm{C} 3 \% \mathrm{~A} 7 \% \mathrm{C} 3 \% \mathrm{~A} 3 \mathrm{o}+$ premiada\&hl=pt-BR\&as_sdt=0\%2C5\&as_ylo=2014\&as_yhi=2019. 
Research done on February 10, 2019, at 10 am: https:/scholar.google.com/ scholar?q $=$ dela $\% \mathrm{C} 3 \% \mathrm{~A} 7 \% \mathrm{C} 3 \% \mathrm{~A} 3 \mathrm{o}+$ colabora $\% \mathrm{C} 3 \% \mathrm{~A} 7 \% \mathrm{C} 3 \% \mathrm{~A} 3 \mathrm{o}+$ premiada\&hl=pt-BR\&as_sdt=0\%2C5\&as_ylo=2001\&as_yhi=2013.

Research done on February 10, 2019, at 10:05 am: https://scholar.google.com/ scholar?q=dela $\% \mathrm{C} 3 \% \mathrm{~A} 7 \% \mathrm{C} 3 \% \mathrm{~A} 3 \mathrm{o}+$ colabora $\% \mathrm{C} 3 \% \mathrm{~A} 7 \% \mathrm{C} 3 \% \mathrm{~A} 3 \mathrm{o}+$ premiada\&hl=pt-BR\&as_sdt=0\%2C5\&as_ylo=1990\&as_yhi=2000.

\section{CLARA MARIA ROMAN BORGES}

Master and PhD by Federal University of Paraná, Brazil. Visiting researcher at the Max-Planck-Institute für Europäische Rechtsgeschichte. Associate Professor at the Department of Criminal Law and Criminal Procedure at Federal University of Paraná. Professor of the Postgraduate Program in Law at Federal University of Paraná. Professor of the Undergraduate and Professional Masters Course at Universidade Positivo.

Professional Address: Federal University of Paraná, Praça Santos Andrade, 50 - 3rd Floor - Centro, Curitiba - PR, 80020-300.

ORCID ID: https://orcid.org/0000-0003-3655-2774

E-MAIL: claraborges@icloud.com

Received: 2020.04.14

Accepted: 2021.04 .20 